DOI 10.31558/2519-2949.2020.2.19

УДК 327.7:341.1/8

ORCID ID: https://orcid.org/0000-0002-0315-5222

Цеховалова А. О., Одеський національний університет ім. I. І. Мечникова

\title{
ПОЗИЦІЯ ФРН ЩОДО ГУМАНІТАРНОЇ ІНТЕРВЕНЦІЇ В ЛІВІЇ
}

Стаття має на меті виявлення особливостей позиції ФРН щзодо проведення гуманітарної інтервениї в Лівії у 2011 р. Німеччина втрималася від голосування по резолюиії 1973 Ради Безпеки ООН. ФРН не підтримала військовий варіант вирімення конфлікту, як ие було передбачено в пунктах 4 i 8 резолючії. Німеччина не мала наміру спонсорувати чужі війська. Вона зайняла іншу позицію ніж ї̈ головні союзники - Франція, Великобританія й США. Причина пов'язана не з розбіжностями із союзниками по Альянсу, а із внутрішньополітичним тиском на коаліційний уряд. Ще одним цікавим поясненням для урядової політики є економічні показники, за якими Лівія не відігравала важливої ролі у німецькій економіці. Можна зробити висновок, що уряд СДУ/ФДП ухвалив рішення утриматися на голосуванні ООН по резолюиії 1973, тому щз це не було пріоритетним питанням для ФРН, і тому, що Гідо Вестервелле вважав, щзо цілі Франції, Великобританії й США могли бути досягнуті без інтервениії, за допомогою санкиій. Обмежена роль Німеччини у лівійській кризі й ї̈ особлива політика у рамках НАТО дозволяє припустити, що німечькі політичні діячі, зіштовхнувшись із фінансовою кризою і ї̈ потенційними наслідками в Свропі, свідомо прагнули обмежити міжнародні зобов'язання Німеччини й тому відмовилися брати участь у забезпеченні нелітної зони. Тим не мени, репутація Німеччини серед ї̈ західних союзників була майже розбита. Утримання уряду Меркель спричинило не просто здивування ії найближчих союзників - Франиї̈, Британії та США, - а звинувачення Берліну в грі на боиі Росії. Німеччина стала вважатися ненадійним союзником. Однак, рімення не брати участь в операції у Лівії свідчить, що Німеччина буде продовжувати оцінювати кожну воєнну операцію на своїх власних умовах, а не відбивати британську й франиузьку політику.

Ключові слова: Лівія, ФРН, доктрина «обов'язку захищати» (R2P), превентивна гуманітарна інтервенція.

Постановка проблеми. Багатонаціональна воєнна операція у Лівії 2011 р., перша операція, проведена відповідно до доктрини «обов'язку захищати», стала серйозним випробуванням превентивної гуманітарної інтервенції як основного інструменту R2P. Операція показала всі проблеми такої інтервенції. Суперечки із приводу місії в Лівії заважають обговоренню нових подібних місій у Сирії та інших конфліктних регіонах планети. У 2011 р. Рада Безпеки ООН схвалила Резолюцію 1973 [1]. Примусове втручання у Лівії призвало членів ООН використати «усі необхідні заходи ... для захисту мирних територій і територій, населених цивільними особами» [1]. Однак, після початку операції США та їх союзників по НАТО, швидко виявилося, що одностайності думок всередині Альянсу досягти не вдасться. Це нашкодило військовій операції та в цілому стосункам США та західноєвропейських країн, не говорячи про сумнівні для лівійців наслідки зовнішнього втручання. Тому проблема позиції ключових європейських гравців, які не підтримали США, $є$ важливою для вироблення майбутніх сценаріїв регіональної та глобальної безпеки. У цьому сенсі приклад ФРН є типовим, але все ще маловивченим наукою про міжнародні відносини.

Огляд літератури показав, що основна маса публікацій зроблена в суміжних науках правознавстві та політології, але думки науковців суттєво розбігаються щодо оцінок позиції ФРН. Так, на думку Гунтера Хеллманна, криза у Лівії «є доказом затяжного коректування у зміненому міжнародному середовищі, що характеризується ускладненням ситуації для німецької держави» [2, c. 46]. Однак, Хеллманн доводить, що зростаюча впевненість Німеччини у своїх можливостях пов'язана з більшою інформованістю в ії̈ силах. Але відсутність надійної німецької зовнішньої політики - як реакції на кризу в Лівії - припускає, що, незважаючи на міцнішу позицію Німеччини, вона, як і раніше, схиляється до компромісу в питаннях сили, інтересів і ідентичності [2, с. 47]. Більш критичний огляд німецької політики знаходимо у Тімоті Гартон Еша. Він критикував 
Німеччину за позицію, яка «залишає нас одних у наших відносинах зі світом й мріє стати великою Швейцарією» [3]. Об'єднання ФРН та НДР попри побоювання невдовзі зміцнило державу та дало їй можливість вимагати більшої фінансової відповідальності від своїх партнерів по єврозоні, а також збільшило іiі роль в Афганістані. Якщо ж тепер випадок Лівії продемонструє, що «прийняте в Берліні рішення буде поширене на подальшу німецьку зовнішню політику, це означало би розрив із попередньою політикою Берлінської республіки» [3]. Алістер Міскіммон також критикую ФРН у 2011 р. На його думку, «розбіжність у зовнішній політиці з Великобританією, Францією й США приводить до важливих наслідків. Замість того, щоб погодитися із загальним рішенням, Німеччина голосно заявила про свої побоювання щодо конфлікту й вважала більш вигідним для курсу своєї зовнішньої політики втриматися〉 [4, с. 393]. Політолог особливо вдало аналізує внутрішні причини такої поведінки держави. «По-перше, німецька політична культура продовжує демонструвати явний протест, коли мова йде про використання військової сили. По-друге, Німеччина не вважала, що участь у воєнній операції в ії національних інтересах. Внутрішні політичні розрахунки змусили правлячу коаліцію ставити інтереси державної політики вище зовнішньої. Зростаюча німецька впевненість у зовнішній політиці означає, що вона буде брати участь тільки в багатонаціональних операціях, які прямо впливають на її національні інтереси. По-третє, у зовнішній політиці Німеччині не вистачає погодженості, а міністр закордонних справ Гідо Вестервелле не повною мірою врахував наслідки утримання від участі» [4, с. 395]. За Міскіммоном, $є$ три наслідки для зовнішньої політики Німеччини, які слід трактувати з позицій політичного реалізму. «По-перше, німецька стратегічна поведінка була більш стійкою до адаптації у результаті впливу ЗПБО ЄС та рішень НАТО. Подруге, сьогоднішне покоління німецьких лідерів вибирає короткострокові привілеї замість зобов'язань. I нарешті, по-третє, своїм бажанням знайти більше можливостей для маневрів існує погроза недооцінити існуючих партнерів і створити загрозу зовнішньополітичним інтересам Німеччини» [4, с. 404].

Таким чином, аналізуючи «білі плями» у сучасних дослідженнях, була сформульована мета статті - виявлення внутрішніх та зовнішніх чинників особливої позиції ФРН щодо гуманітарної інтервенції у Лівії в 2011 p.

Боротьба Німеччини за перегляд засад своєї зовнішньої політики була на початку XXI ст. дуже сильною. Німецькі політики підкреслювали, що Німеччина є надійним і передбачуваним партнером для своїх союзників. У програмній промові з зовнішньої політики у жовтні 2010 р. міністр закордонних справ Гідо Вестервелле так позначив основні аспекти зовнішньої політики Німеччини: «Німецька зовнішня політика грунтується на наступності попередніх десятиліть. Вона надійна й передбачувана, орієнтована на наші цінності й інтереси, є двигуном для політичної відкритості й економічного розвитку. Зовнішня політика Німеччини виступає за рівність та узгодження інтересів» [5].

У лютому 2011 р. протести лівійського цивільного населення спочатку були подавлені полковником Муаммаром Каддафі. Але хвилювання швидко загострилися настільки, що державичлени $\mathrm{CC} \mathrm{вжили} \mathrm{заходів} \mathrm{щодо} \mathrm{репатріації} \mathrm{своїх} \mathrm{громадян.} \mathrm{Напередодні} \mathrm{початку} \mathrm{обговорення}$ нелітної зони, 26 лютого 2011 р. німецька авіація врятувала 134 співробітників Wintershall AG, двадцять два з яких були громадянами ФРН [4, с. 394]. Це продемонструвало швидкі й рішучі дії з боку німецького уряду, коли вони вважали їх за потрібні.

Але 17 березня 2011 р. Петер Віттіг, посол Німеччини в ООН, зробив наступну заяву: «Завжди важко ухвалити рішення щодо використання військової сили. Ми уважно розглянули варіанти іiі застосування, наслідку, а також свої припустимі границі. Ми бачимо великий ризик. Не слід недооцінювати ймовірність великомасштабних людських втрат. Якщо пропоновані заходи виявляться неефективними, існує погроза потрапити до затяжного військового конфлікту, який торкнеться куди більших територій. Ми не повинні вводити війська, при цьому оптимістично запевняючи, що це дасть швидкі результати з малими втратами» [6].

Отже, Німеччина втрималася від голосування по резолюції 1973 Ради Безпеки ООН. ФРН від початку не підтримала військовий варіант вирішення конфлікту, як це було передбачено в пунктах 4 і 8 резолюції. Крім того, Німеччина не мала наміру спонсорувати чужі війська. Вона зайняла іншу позицію ніж ії головні союзники - Франція, Великобританія й США - й відповідно опинилася поряд з Росією, Китаєм, Індією та Бразилією [7].

Це потребує розуміння чинників зовнішньої політики ФРН. Перша здогадка, що приходила на думку аналітикам у 2011 р., це розбіжності у поглядах на свою роль у загальноєвропейський політиці між основними іiі акторами. Дійсно, у завуальованому нападі на франко-британські 
плани щодо Лівії, міністр оборони ФРН Томас де Мезьєр заявив: «Наше рішення не брати участь у військовій частині місії у Лівії було засновано на ретельно продуманих причинах. ...Відповідальність щодо захисту цивільного населення країни, якщо його уряд порушує права людини, міцно закріплена у міжнародному праві. Але чи значить це, що ми маємо право втрутитися? Або це значить, що ми не зобов'язані цього робити? Я вважаю, що кожна воєнна операція повинна бути проаналізована, щоб визначити, чи можуть іiі цілі бути досягнуті за допомогою відповідних факторів і протягом відповідного періоду часу, а також, як довести справу до кінця. Усе» [8]. Обережність де Мезьєра із приводу військової інтервенції в Лівії була виражена у такий спосіб: «Незважаючи на те, серце говорить «так» (за військову місію), тверезе судження говорить: «дайте їм спокій» [8]. У той же час, щоб пом'якшити різкість реакції своїх основних союзників, Німеччина погодилася відправити додатково 300 бійців до AWACS (Airborne Warning and Control System) у Афганістані, щоб звільнити сили НАТО для нелітної операції у Лівії [9].

Інша версія пов'язана не з розбіжностями із союзниками по Альянсу, а із внутрішньополітичним тиском на коаліційний уряд, тиском тих, хто завжди намагався утримати ФРН від активних дій за межами країни та який на той момент переважив всі інші міркування. Уряд зосередився на ризиках для німецьких військ, які могли бути утягнені у розширений конфлікт. Політики, зокрема Гідо Вестервелле, який став центральною фігурою у рішенні втриматися від UN1973, вважали, що криза в Лівії все ще може бути вирішена за допомогою дипломатичних i економічних інструментів. Утримання від резолюції 1973 частково було виборчою тактикою СвДП у світлі майбутніх виборів у Баден-Вюртемберзі 27 березня 2011 р. Побоюючись, що СвДП не пройде виборчий поріг у 5 відсотків, Вестервелле підрахував, що його поміркованість у зовнішній політиці буде кориснішою. Так, за опитуванням Bild Sonntag 20 березня 2011 р., 62\% респондентів були за військову місію в Лівії, 31\% проти. Але, коли їх запитали, чи слід брати участь німецьким збройним силам в цій операції, 65\% респондентів відповіли «ні» і 29\% «так» [10, с. 72].

Ще одним цікавим поясненням для урядової політики є також економічні показники, за якими Лівія не відігравала важливої ролі у німецькій економіці. У 2010 р. Лівія оцінювалася як шістдесят шоста у списку країн німецького експорту, й тридцять восьма з погляду імпорту у Німеччину. До кризи 2011 р. 14\% нафти Лівії надходили у Німеччину, 32\% в Італію й 10\% у Францію. Але якщо остання виражала велику зацікавленість у збільшенні цього обсягу. ФРН намагалася скоротити енергомісткість свого виробництва, отже й залежність від експорту енергоносіїв. Цікаво, що голосуючи так само, як РФ, Китай, Індія й Бразилія, Німеччина поставила себе поряд економік, що розвиваються. Ця причина додає світла при розгляді німецької стратегії та іï характеристики як держави, що насамперед керується геоекономічними чинниками [11]. На противагу ФРН, Великобританія й Франція використовували Лівію в роки після кризи 2011 р. для поставок сирої нафти в результаті зниження поставок з Північного моря. У світлі економічних тисків, пов'язаних із кризою єврозони, мінливий політичний клімат у межах Німеччини й іï енергетична стратегія, сприяла відносинам з Росією й колишніми радянськими республіками, навіть із Близьким Сходом, тож Німеччина не бачила явних причин бути замішаною в операцію НАТО. Британська й французька зростаюча залежність від лівійської нафти припускають вважати, що у Лівії інтереси безпеки Лондона й Парижа та їх економічні інтереси збіглися й вони почали спроби стабілізувати Лівію будь-якими засобами через свої національні інтереси. Німеччина ж зосередилася на Східній Європі, щоб забезпечити себе енергоресурсами на майбутнє, що у свою чергу все більше впливає на вироблення німецької зовнішньої політики.

Якщо позиція ФРН відразу обурила союзників по НАТО, то й всередині країни урядова політика була піддана критиці. Лідер СДПГ Зігмар Габріель спочатку підтримав рішення уряду, але потім почав його критикувати, на відміну від лідера «Зелених» Цема Оздеміра, що критикував Вестервелле від самого початку з гаслом, що «не гідно Німеччини ігнорувати права людини» в Лівії [12, с. 550]. Однак, всередині цих партій єдності також не було. Отже, при відсутності чітких партійних політичних ліній щодо випадку Лівії, тиск на уряд було обмежено. У центрі ж уваги самого уряду було перш за все збереження статус-кво уперіод бюджетної консолідації, а не розробка будь-яких нових можливостей i цілей. У галузі зовнішньої політики Берлін сфокусувався на територіальній обороні. Після реформ за рекомендаціями структурної комісії Бундесверу рівень амбіцій Німеччини скоротився відповідно до різкого скорочення загальної кількості ЗС з 16 до 10 тисяч [12, с. 557]. 
Отже, можна зробити висновок, що уряд СДУ/ФДП ухвалив рішення утриматися на голосуванні ООН по резолюції 1973, тому що це не було пріоритетним питанням для ФРН, i тому, що Вестервелле вважав, що цілі Франції, Великобританії й США могли бути досягнуті без інтервенції, просто за допомогою санкцій.

У міру розвитку кризи, однак, рішення Вестервелле і його наслідки для зовнішньої політики Німеччини привело до критики уряду, ширших питань із приводу всієї зовнішньої політики Ангели Меркель. Головним критиком Вестервелле став колишній міністр закордонних справ Йошка Фішер, який стверджував, що ця помилка відзначила найнижчий рівень німецького впливу на зовнішню політику ЄС й в майбутньому загрожує нашкодити німецькій зовнішній політиці й спробам ЄС налагодити вагомішу роль у міжнародних справах. Фішер заявив, що «Німеччина втратила довіру 3 боку ООН і Близького Сходу... Німецькі надії на постійне місце в Раді Безпеки були назавжди перекреслені й тепер слід боятися майбутнього» [13]. Колишній федеральний президент Роман Херцог стверджував, що за участю Німеччини у Боснії у 1990-х рр. об'єднана Німеччина привнесла нову відповідальність у міжнародні відносини. Він припустив, що «Німеччина належить до списку великих демократичних держав, подобається це ій чи ні, і якщо одна із цих демократичних держав залишається осторонь, вона неминуче шкодить не тільки іншим, але й собі. Ми бачимо ще більш ясно, що несхильна до ризику бездіяльність може в остаточному підсумку бути більш ризикованою, ніж потенційно небезпечна дія... Якщо ми не будемо протистояти ризикам у місцевому масштабі, то вони наздоженуть нас» [14].

Захищаючи свою позицію, Вестервелле підкреслив ризики участі у будь-якій воєнній операції, натякаючи на досвід НАТО в Афганістані: «Наша позиція така не тому, що ми зм'якшили своє відношення до системи Каддафі, а тому, що ми повинні бачити ризики тривалих збройних місій» [15]. Стверджуючи, що за допомогою мирної стратегії можна скинути Каддафі, Вестервелле опирався на ключовий для ФРН принцип «геншеризму», намагаючись знайти мирне дипломатичне рішення й обмежити німецьку військову участь в операції НАТО [докладніше: 16].

Коли лівійські повстанці вступили у Тріполі наприкінці серпня 2011 р., сповіщаючи про початок кінця режиму Каддафі, Вестервелле заявив, що саме санкції й політичний тиск Німеччини підірвали позиції лівійського лідера й зіграли важливу роль у його падінні [17]. Отже, обмежена роль Німеччини в лівійській кризі й їі особлива політика у рамках НАТО дозволяє припустити, що німецькі політичні діячі, зіштовхнувшись із фінансовою кризою і іiі потенційними наслідками в Свропі, свідомо прагнули обмежити міжнародні зобов'язання Німеччини й тому відмовилися брати участь у забезпеченні нелітної зони. Тим не менш, дев'ять років тому репутація Німеччини серед її західних союзників була майже розбита. Щойно ФРН зайняла позицію у Раді Безпеки ООН, коли було оголошене голосування за втручання у Лівію за мандатом «обов'язку захищати». Утримання уряду Меркель спричинило не просто здивування іiї найближчих союзників - Франції, Британії та США, - а звинувачення Берліну в грі на боці Росії. Німеччина стала вважатися ненадійним союзником.

Висновки. Внутрішні чинники, пов'язані із кризою єврозони й бажанням знизити залучення Німеччини в багатосторонні операції, лежать в основі рішення про відмову в підтримці щодо створення нелітної зони в Лівії. Як показали події гуманітарної інтервенції у Лівії, рішення Німеччини не приймати участі в операції НАТО було правильним, хоча уряд Меркель скоріше не зміг вчасно обгрунтувати його й довести до всіх зацікавлених сторін.

Меркель бачила, як військова коаліція під керівництвом США в Іраку закінчилася невдачею. На день, коли режим Саддама Хуссейна було скинуто, у США не було подальшого плану. Те саме повторилося і у Лівії. Коли полковника Каддафі було відсторонено, ні НАТО, ні ООН не мали плану на наступний день. Франція та Німеччина повинні були заплатити дуже високу ціну за війну в Лівії. Армії, які діяли в Лівії, швидко пішли, рушивши зі зброєю до Малі та інших місць Сахелю. Відтоді Франція, колишня колоніальна держава, веде війну - за підтримки США - за стримування ісламського тероризму, торгівлі людьми та зростання нестабільності. 3 війнами, а також нестабільним сусідством, Лівія стала одним з головних маршрутів для мігрантів та біженців, які бажають перетнути Середземномор'я до Європи. Зусилля ЄС щодо стримування потоку шляхом розгортання операції «Софія», як мінімум, неоднозначні. Красномовною є кількість жертв у цілому. Отже, Німеччині не варто шкодувати про своє рішення.

Незважаючи на значний досвід у колишній Югославії, Афганістані й інших країнах, Німеччина усе ще бореться з поширенням силових методів вирішення міжнародних проблем. Участь Німеччини в операції союзницьких сил у Косово у 1999 р. стала основою громадського осуду 
причетності ФРН до військових криз. Рішення не брати участь в операції у Лівії свідчить, що Німеччина буде продовжувати оцінювати кожну воєнну операцію на своїх власних умовах, а не відбивати британську й французьку політику.

У 2015 р., коли війна в Сирії призвела до невимовних страждань цивільних осіб, Меркель відкрила кордони для понад одного мільйона людей, які рятуються від війни. Меркель тільки 3 етичних та гуманітарних міркувань вирішила надати так багато потрібного притулку людям. Отже, вона «успадкувала» невдалу політику НАТО в Лівії, невдалу політику США в Іраку та ганебну дипломатичну та політичну невдачу Заходу в Сирії.

Залежно від того, як розглядалося це ії рішення, канцлер заплатила високу ціну. «Альтернатива для Німеччини», антиіміграційна, антимусульманська та антисемітська партія, наразі користується величезною популярністю в Німеччині, особливо в східних землях. Це не може розглядатися тільки як короткочасне явище або сплеск. Але у подальшому позиція ФРН 2011 р. може принести зовнішньополітичні дивіденди. Саме тому, що вона утрималася під час голосування за Лівію в 2011 р., Німеччина може бути сприйнята як нейтральна сторона для організації конференції в/по Лівії, якщо міжнародна спільнота виявить схильність перейти від силових до несилових методів боротьби за мир та стабільність у регіоні.

\section{Бібліографічний список/References:}

1. UN Security Council Resolution 1973, March 17, 2011, para 4.

2. Hellmann G. Normatively Disarmed, But Self-Confident. Internationale Politik. Global Edition. 2011. N 3. P. 45-51.

3. Garton Ash T. France Plays Hawk, Germany Demurs: Libya Has Exposed Europe's Fault Lines / Timothy Garton Ash. Guardian, 24 March 2011. URL: http://www.guardian.co.uk/commentisfree/2011/mar/24/france-hawkgermany-demurs-libya-europe

4. Miskimmon A. German Foreign Policy and the Libya Crisis. German Politics. 2012. Vol. 21, N 4. P. 392-410. DOI: $10.1080 / 09644008.2012 .739610$

5. Westerwelle G. Speech to the German Council on Foreign Relations. Deutsche Welle, 21 October 2010.

6. Wittig P. Explanation of Vote by Ambassador Wittig on the Security Council Resolution on Libya.

New Yorker, 17 March 2011.

7. Tisdall S. Libya: Reaction: Britain and France Appear Ever More Isolated as World Opinion Turns Hostile:

China, Russia, Germany, Brazil Voice Objections NATO Also Divided as Turkey Blocks Agreement. Guardian, 22 March 2011.

8. Germany Defends Cautious Approach to Libya, Denies Isolation. Deutsche Welle, 21 March 2011.

URL: http://www.dw-world.de/dw/article/0,,14926360,00.html

9. Merkel Cabinet Agrees AWACS for Afghanistan. Der Spiegel, 23 March 2011.

URL: http://www.spiegel.de/international/world/0,1518,752709,00.html

10. Paterson W. E. The Reluctant Hegemon: Germany Moves Centre Stage in the EU. Journal of Common Market Studies. 2011. N 49. P. 57-75.

11. Foreign Trade, 2010 - 2017. Statistisches Bundesamt. URL: https://www.destatis.de/SiteGlobals/

12. Dyson T. Condemned Forever to Becoming but Never to Being? The Weise Commission and German

Military Isomorphism. German Politics. 2011. Vol. 20, N 4. P. 545-567.

13. Fischer Joins Criticism of German Security Council Abstention. Der Spiegel, 22 March 2011.

URL: http://www.spiegel.de/international/germany/0,1518,752542,00.html

14. Wolf M. The Riddle of German Self-Interest. Financial Times, 30 May 2012.

15. Genscher H.-D. Rebuilding a House Divided. New York: Broadway Books, 1998. 592 p.

16. Germany Defends Cautious Approach to Libya, Denies Isolation. Deutsche Welle, 21 March 2011. URL: http://www.dw-world.de/dw/article/0,,14926360,00.html

\section{Tsekhovalova A. O. Germany's Position on Humanitarian Intervention in Libya}

The article aims to identify the specifics of the position of Germany on humanitarian intervention in Libya in 2011. Germany abstained from voting on UN Security Council Resolution 1973. Germany did not support a military solution to the conflict as provided for in paragraphs 4 and 8 of the Resolution. Germany did not intend to sponsor foreign troops. It has taken a different position than its main allies - France, Great Britain, and the United States. The reason is not due to disagreements with allies in the Alliance, but due to domestic political pressure on the coalition government. Another interesting explanation for government policy is the economic indicators according to which Libya did not play an important role in the German economy. It can be concluded that the USD / FDR government decided to abstain from the UN vote on Resolution 1973 because it was not a priority for Germany and because Guido Westerwelle believed that the goals of France, Britain and the United States could be achieved without intervention, 
only through sanctions. Germany's limited role in the Libyan crisis and its special NATO policies suggest that German politicians, faced with the financial crisis and its potential consequences in Europe, deliberately sought to limit Germany's international obligations and therefore refused to participate in securing the no-fly zone. However, Germany's reputation among its Western allies was almost shattered. The Merkel government's retention has surprised not only its closest allies - France, Britain and the United States - but also accused Berlin of playing on Russia's side. Germany became considered an unreliable ally. However, the decision not to take part in the operation in Libya indicates that Germany will continue to evaluate each military operation on its own terms, rather than reflecting British and French policies.

Key words: Libya, FRG, the doctrine of "Responsibility to Protect" (R2P), preventive humanitarian intervention. 